\title{
CASH FLOW AND INVESTMENT: EVIDENCE FROM INTERNAL CAPITAL MARKETS
}

\author{
Owen Lamont
}

Working Paper 5499

\section{NATIONAL BUREAU OF ECONOMIC RESEARCH 1050 Massachusetts Avenue \\ Cambridge, MA 02138 March 1996}

I thank the National Science Foundation and the Alfred P. Sloan Foundation for financial support, and Andrew Bernard, Olivier Jean Blanchard, David Brown, Ricardo Caballero, Judith Chevalier, Robert S. Chirinko, Guy Debelle, Charles Hadlock, Paul Healy, Anil Kashyap, Jim Poterba, David Scharfstein, Jeremy Stein, Rene Stulz, David Wilcox, an anonymous referee, and seminar participants at numerous institutions for helpful comments, and Amy C. Ko and Sydney Ludvigson for research assistance. This paper is part of NBER's research programs in Corporate Finance, Industrial Organization and Monetary Economics. Any opinions expressed are those of the author and not those of the National Bureau of Economic Research.

(C) 1996 by Owen Lamont. All rights reserved. Short sections of text, not to exceed two paragraphs, may be quoted without explicit permission provided that full credit, including (C) notice, is given to the source. 


\title{
CASH FLOW AND INVESTMENT: EVIDENCE FROM INTERNAL CAPITAL MARKETS
}

\begin{abstract}
Using data from the 1986 oil price decrease, I examine the capital expenditures of non-oil subsidiaries of oil companies. I test the joint hypothesis that 1) a decrease in cash/collateral decreases investment, holding fixed the profitability of investment, and 2) the finance costs of different parts of the same corporation are interdependent. The results support this joint hypothesis: oil companies significantly reduced their non-oil investment compared to the median industry investment. The 1986 decline in investment was concentrated in non-oil units that were subsidized by the rest of the company in 1985 .
\end{abstract}

Owen Lamont

Graduate School of Business

University of Chicago

1101 East 58th Street

Chicago, IL 60637

and NBER 


\section{Cash flow and investment: Evidence from internal capital markets}

Suppose that a company's cash flow or collateral value falls, but the profitability of its investment opportunities stays constant (or rises). Would this company reduce its investment? In this paper I try to answer this question by examining how different parts of the same firm reacted to the 1986 oil price decline, which reduced the cash flow and collateral value of oil firms. Using the Compustat database, I identify a group of firms which have corporate segments both in the oil extraction industry and in non-oil industries, where "non-oil" is defined as an industry with profits that are not (positively) correlated with the price of oil. I then test the hypothesis: do large cash flow/collateral value decreases to a corporation's oil segment decrease investment in its non-oil segment?

I focus on the 1986 oil shock, in which oil prices fell by 50 percent, because this dramatic economic event seems unambiguously exogenous to any individual firm. Looking within firms, rather than across firms, I test the joint hypothesis that 1) the oil shock affected the costs of finance for oil segments, and 2) the cost of finance in the oil segment affected the cost of finance in the non-oil segment of the company. This joint hypothesis would be true if both external capital markets were imperfect (so that financial slack matters for investment) and if internal capital markets allocated capital within firms (so that the different parts of the firm are interdependent). It is of interest both to macroeconomics, because investment is an important part of the business cycle, and to corporate finance, because the financing of investment is a central purpose of corporate capital structure.

I begin by discussing the two parts of the joint hypothesis. I then describe the 
macroeconomic background, data, and sample selection issues. I perform several statistical tests with the data, examining medians, means, and regression coefficients. I compare the non-oil segments owned by oil companies with similar segments owned by companies which are less dependent on oil. The empirical tests reject the null hypothesis: oil companies significantly reduced their non-oil investment in 1986. Although the sample size is fairly small, the results appear moderately robust. These investment reductions were concentrated in segments which were not self-financing in 1985 . The findings are consistent with previous research which suggests that diversified companies tend to subsidize and overinvest in poorly-performing segments.

\section{A. Liquidity and Investment}

A large literature in corporate finance and macroeconomics documents the relationship between liquidity and investment (see Fazzari, Hubbard and Petersen (1988); Hoshi, Kashyap, and Scharfstein (1991)). Although a strong correlation between cash (whether measured as a flow, a stock, or both) and investment is a well-documented fact, the causal connection between the two has been harder to establish, since both investment and cash flow are driven by underlying shocks to profitability. Existing studies have attempted to control for the profitability of investment by including a measure of Tobin's $q$ in the estimated equation, but since current profitability may well be a better measure of the future profitability of investment than stock market data, the estimated coefficients may be biased.

Since exogenous instruments for cash that are uncorrelated with the profitability of investment are difficult to find, researchers instead have focused on the examining the differences in cash-investment correlations between groups of firms hypothesized to have different dependence 
on internal finance. Studies typically use panel data on firms to estimate:

$$
I / K=a+b Q+c C A S H / K+Y E A R D U M M Y+F I R M D U M M Y
$$

where $I$ is investment, $K$ is capital stock at the beginning of the period, $q$ is Tobin's $\mathrm{q}$, and $C A S H$ is a measure of cash flow or cash stock. To test the hypothesis that two groups of firms face different finance constraints, the coefficient $c$ on cash is compared across different firms, with firms categorized according to dividend payout ratios (Fazzari, Hubbard, and Petersen (1988)), bond rating (Whited (1992)), or membership in a Japanese keiretsu (Hoshi, Kashyap, and Scharfstein (1991)). Another test is to compare coefficient $c$ across different time periods with different macroeconomic-credit conditions (Gertler and Hubbard (1988), Kashyap, Lamont, and Stein (1994)).

However, looking at differences in cash-investment correlations may still be a less than perfect test. It may be that innovations in cash have different implications for the profitability of investment in small and large firms (Gilchrist and Himmelberg (1992)). Alternatively, it may be that $q$ is more poorly measured for small firms (as noted in Poterba (1988)).

This paper takes a different route, and seeks to find an exogenous instrument for cash. By focusing on a small group of corporate units, I can unambiguously identify shocks to cash which are not correlated (or at least, not positively correlated) with the returns to investment. The basic idea is to find a natural experiment in which one can identify specific changes in the cost of finance. A similar strategy is used by Blanchard, Lopez-de-Silanes, and Shleifer (1994), who examine a small (eleven) group of firms that experience a cash windfall. In contrast, this study examines a somewhat larger group of firms that experience a cash shortfall, and compares their investment with a control group of similar companies that do not experience a cash shortfall. 
The innovation in the present paper is the use of corporate segment-level data. In the United States, publicly-owned firms are required to report certain data disaggregated into corporate segments, with a segment for each different industry in which the company participates. The new data set used here brings new issues (both econometric and conceptual), and by focusing on the 1986 episode I chose a different balance in the trade-off between sample size and econometric bias. Thus the data presented here is useful but imperfect evidence on the connection between finance costs and investment.

A simple perfect capital markets model implies that when a company's oil segment cash flow falls, the same company's non-oil segment should be unaffected if the net present value of non-oil investment is unaffected. An imperfect capital markets model implies, in contrast, that when financial constraints tighten, the shadow cost of investment rises for all projects, so that the amount of investment (ceteris paribus) falls for all divisions of the firm.

\section{B. Internal capital markets}

Internal capital markets are a major channel of capital allocation in modern industrial economies. In any firm, managers must allocate capital across different projects. External finance is sometimes earmarked for particular parts of the firm or secured by specific assets (e.g. project finance). Internal funds can be more fungible, and finance the bulk of investment. For example, between 1981 and 1991, internal funds accounted for more than three quarters of capital outlays for US nonfinancial corporations.

Internal capital markets may differ from external capital markets due to differences in information, incentives, asset specificity, control rights, or transactions costs (see Alchian (1969), Grossman and Hart (1986), Gertner, Scharfstein, and Stein (1994), Stein(1995)). Corporations 
may own multiple assets due to product market synergies, increases in managerial efficiency, or improvements in capital allocation.

These issues are not explored here; instead, I simply outline the hypothesis to be tested. The alternative hypothesis is a joint hypothesis that both external markets are imperfect and that corporate segments are financially interdependent; internal capital markets play a nontrivial role in allocating capital. Under this hypothesis, combining diverse businesses into a corporate whole would alter the investment and financing behavior of the component companies. Of course, it need not be true that the financing of the company's segments is perfectly integrated; that is, the possible imperfections of the external capital market may be mirrored in the internal capital market.

The null hypothesis is that corporate segments operate as stand-alone units; there are no internal capital markets, and each segment finances its investment from its own internal finance or from external finance secured by its own collateral. Corporations operate multiple lines of business for reasons of product market synergy, or because scarce managerial talent is best used supervising a wide range of activity.

If different corporate segments are financially interdependent, then a financial shock to one segment affects the cost of finance in another segment. In the case of the oil shock, financial constraints tightened in two related ways. First, the internal finance available to the company its cash flow generated by oil - fell. Second, the value of the petroleum-related collateral owned by the company also fell, so external finance may have been more difficult to obtain.

Note that internal capital markets may have macroeconomic implications. Existing macroeconomic research emphasizes the role of banks, securities markets, and other external 
capital markets in the transmission of business cycles. Internal capital markets (in diversified firms) also provide a channel through which shocks can be transmitted from one sector to another.

\section{The Oil Shock of 1986}

In late 1985, Saudi Arabia appeared to deliberately change its petroleum policy, and increased production. Figure 1 shows the result: crude oil prices responded dramatically, falling from $\$ 26.60$ per barrel in December 1985 to $\$ 12.67$ in April 1986. Table I shows the effect this plunge had on major US oil companies: profit rates for petroleum fell markedly. Table I also shows that oil and gas production was hit much harder than other petroleum-related segments. Therefore, this paper focuses largely on the shock to oil and gas production/extraction industries (as opposed to refining or transportation).

Evidence on whether the oil price crash was anticipated is mixed. On one hand, oil prices had been declining slowly in real terms throughout the mid-1980s and were weak in 1985, and many observers predicted a decline in oil prices due to OPEC's continuing internal turmoil. On the other hand, contemporary press accounts indicate that the depth and rapidity of the oil price decline surprised many participants.

Oil companies certainly dramatically altered their plans in the first quarter of 1986. According to a Department of Commerce survey conducted in October 1985, petroleum companies planned a 3.4 percent increase in (predominantly oil-related) capital expenditures in 1986 compared to 1985 . By April, 1986, the same survey indicated a planned 24.4 percent fall in capital expenditures in $1986 .^{1}$ For the companies which comprise the dataset, downward revisions of total planned 1986 investment ranged from 20 percent (Unocal) to 51 percent (Homestake Mining Company). ${ }^{2}$ Unfortunately, most companies did not report the industry 
details of their expected and revised 1986 investment plans, which would have been ideal for the hypothesis test in this paper.

For at least one company in the sample, company officials explicitly stated that they were cutting non-oil investment as a result of the oil price crash:

Chevron Corp. cut its planned 1986 capital and exploratory budget by about 30 percent because of the plunge in oil prices...A Chevron spokesman said that spending cuts would be across the board and that no particular operations will bear the brunt.

About 65 percent of the $\$ 3.5$ billion budget will be spent on oil and gas exploration and production - about the same proportion as before the budget revision.

Chevron also will cut spending for refining and marketing, oil and natural gas pipeline, minerals, chemicals, and shipping operations. (Wall Street Journal 3/14/86)

In the terminology of this paper, Chevron's chemical segment is classified as a "non-oil" segment. Note that Chevron's actions appear to be consistent with Shin and Stulz (1995) who look for "bureaucratic rigidity" in the allocation of capital in diversified firms.

\section{Data}

For corporate segments that constitute at least 10 percent of total sales and which are in a different industry from the rest of the corporation, accounting standards require corporations to report five annual variables on a segment-level basis: sales, operating profit, capital expenditures, depreciation, and identifiable total assets. Operating profit is usually reported on a pre-tax basis. The Compustat database reports these five items, along with a pair of SIC codes, for each segment. After examining various documents supplied by the company, Compustat assigns a primary 4-digit SIC industry code to each segment, corresponding to the industry classification of the majority of the segment's sales. If the segment engages in business in more than one 4-digit 
industry, Compustat assigns a secondary SIC code for the next largest part of the segment.

Segment-level accounting data is far from perfect, and may well contain more noise than firm-level accounting data. In particular, firms must (perhaps arbitrarily) divide up overhead costs and assets which may provide benefits to more than one segment. I focus primarily on (appropriately normalized) changes in segment-level capital expenditure data, so that any noise that is constant over time (such as different accounting practices used by different firms) may be alleviated. Since the 1986 shock is quantitatively and economically very large, the size of the effect should be large enough to be discerned despite possible measurement errors in the data.

To gather a sample of firms likely to be affected by the oil price decrease of 1986, I extracted every firm which in 1985 had a segment with either primary or secondary SIC codes in the oil and gas extraction sector (2-digit SIC code 13). I then selected only those firms which I classified, based on 1985 data alone, as being oil-dependent; that is, to have a high ex ante probability of receiving a large decrease in their oil cash flow (relative to their non-oil cash flow) in 1986. I classified firms as being oil-dependent if at least 25 percent of their cash flow in 1985 came from the oil and gas extraction industry (see the appendix for more details).

I then selected those firms which had a non-oil segment, as identified by Compustat's SIC codes for the segment and using my own judgment about which industries were oil-related. ${ }^{3}$ I restricted attention to segments which were not in the financial or services industries, as is standard. ${ }^{4}$ I defined a non-oil industry as any industry which: was not involved in the extraction of or exploration for oil and gas (or by-products of oil and gas extraction); did not primarily involve refining, transporting, or selling petroleum products; did not supply services or equipment to the oil and gas industry; and did not produce a product which was a substitute for petroleum. ${ }^{5}$ 
This meant that, for example, in addition to excluding gas pipelines, retail gasoline distributors, and oilfield services, I also excluded: the coal and uranium industries; manufacturing of valves and other pipeline-related equipment; manufacturing of construction and mining equipment; and sulfur mining (since sulfur is sometimes produced as a by-product of oil extraction). When in doubt, I excluded suspect industries.

I carefully checked the line-of-business descriptions of every segment, and excluded those which I judged likely to be adversely affected by the oil price shock, either because they provided services for the oil and gas extraction industry or operated in a region heavily dependent on oil (a complete list is given in the Data Appendix). For example: I excluded Rowan Companies "Aviation Operations" (a charter aircraft business) because after checking the company documents, I found it operated principally in two oil-related regions, Alaska and the Gulf of Mexico. I was happy to include as non-oil industries those which used oil as an input, since these segments were likely to experience an increase in profitability as a result of the decline in oil prices.

As a check on this judgemental classification procedure, I also examined industry-level data on profits and investment for the non-oil industries with available data. Using data from the Annual Survey of Manufacturing from 1961-1985, I examined the time-series correlation of profits and investment with real oil prices. I was unable to reject the hypothesis that for this group of industries, profits and investment were not positively correlated with the price of oil. ${ }^{6}$

Lastly, as detailed in the data appendix, I deleted segments with incomplete information and segments that were very small.

The resulting sample of 26 diversified, multi-segment firms is shown in Table II. The 
main activity of most of these firms fell into one of five main areas: extracting, refining, and distributing petroleum products; railroads; mining; chemicals; and miscellaneous manufacturing. Most of these firms are quite large (far larger than the average firm on Compustat). A standard result in the cash/investment literature is that liquidity matters less for large firms than for small firms. Fazzari, Hubbard, and Petersen, for example, find that small firms have much higher cash/investment correlations than large firms. ${ }^{7}$ Thus it may be difficult to reject the null hypothesis with this sample of firms.

These 26 firms owned 40 segments, which are presented in Table III. Chemicals and plastics is the largest single industry (with 17 segments) with railroad, mining, agriculture, and paper/lumber products also represented.

\section{A. Survivorship bias}

There is likely a substantial survivorship bias in the data which probably decreases the ability to reject the null hypothesis when it is false. Under the alternative hypothesis that the oil shock increased the cost of finance, financially constrained firms are likely to sell their non-oil segments.

One strand of the imperfect capital markets/financial constraints literature would predict that, as a result of the adverse cash flow shock of 1986, oil-dependent companies would underinvest in their non-oil subsidiaries. One way to mitigate this inefficiency, and at the same time raise cash, is for the firm to sell off some of its divisions. This is precisely what occurred in 1986. Figure 2 shows that non-energy asset disposals in companies tracked by the Department of Energy peaked in $1986 .{ }^{8}$ This process decreases the sample size since this paper includes only non-oil divisions with continuous data; i.e. those that were owned by the same parent company 
Page 11

in both 1985 and 1986. Further, because the firms that were most constrained were the ones most likely to sell divisions, it may bias the results in favor of accepting the null hypothesis.

Major energy producers which sold off petrochemical operations in 1986 include Diamond Shamrock and Enron. Thus these two companies are not represented in our sample. Of the 26 oil firms examined here, at least five discontinued large non-oil operations: Canadian Pacific (airlines and mining); Homestake Mining (silver mining); WR Grace (agricultural chemicals and restaurants); Mobil (paperboard and packaging); and USX Corp (chemicals). For some of these discontinued segments, I was able to find at least partial capital expenditure data in 1986 (with data coming either from the buyer or successor company, or from the original owner). In each case, this data indicated that capital expenditure decreased in 1986 under the original owners, consistent with the hypothesis that investment decreased due to the oil shock. For example, one of the firms in the sample, USX Corp (formerly US Steel) spun-off its chemical segment in October, 1986. The financial statements of the resultant entity, Aristech Chemical, show that capital expenditure fell between 1985 and 1986, when it was (for most of the year) a unit of USX.

\section{Results}

I try to adhere to standard practice by using a dependent variable similar to the left hand side of equation (1). Unfortunately, I do not observe physical assets $(K)$ for corporate segments. Further, since asset sales are likely to be a problem during this period, changes in the size of the segment could drive changes in capital expenditure. Therefore, I focus on the ratio of contemporaneous investment to contemporaneous sales, $I / S$.

The basic empirical strategy is to test the hypothesis in several ways. First, I impose few assumptions on the data, and look only at means and medians. Here I focus on the change in the 
investment to sales ratio between 1985 and 1986. In section IV, having established that investment fell in this period, I attempt to explain this fall by looking at the performance of these non-oil segments and the pattern of intersegment subsidization in 1985 , looking at levels of investment in addition to changes in investment. Last, I come as close as possible to testing the standard equation (1) using oil cash flow and non-oil investment. However, with segment data it is impossible to observe Tobin's $q$ for each segment, since individual corporate segments do not (usually) issue equity. ${ }^{9}$ Because I cannot observe $q$, I pay particular attention to industry-adjusted data.

To be sure that the observed oil cash flow decrease is caused by an exogenous shock, and not by the firm's endogenous response to the shock, I look at both the ex post magnitude of the cash flow decrease in the oil segment in 1986, and the ex ante likelihood that a large decrease would occur. In looking at $e x$ ante data, I use only information on the industry composition of the firm in 1985 , to avoid the possibility that firms which had a large ex post decrease in oil cash flow in 1986 were firms with particularly inept managers.

\section{A. Ex ante tests: $\Delta I / S$}

As can be seen in Table III, most of the non-oil segments experienced an increase in cash flow between 1985 and 1986, in sharp contrast to the performance of the oil industry. Cash flow is defined as the sum of segment operating income and segment depreciation. The average change in the cash flow to sales ratio from Table III is 2.43 percent (with a t-statistic of 2.76 ).

Table IV presents means and medians for the (normalized) levels in segment investment. Based on the evidence from Table III, one might have expected capital expenditures to increase in 1986, since cash flow increased. In fact, Tables III and IV show that just the opposite occurred: 
capital expenditures declined in 1986 for most of the 40 segments, with a mean and median decline of around one percent, compared to the 1985 level of the investment to sales ratio of around eight percent. ${ }^{10}$

Table V presents raw and industry-adjusted changes in investment, and displays some of the major results of this paper. Industry-adjustment is necessary to control for industry-wide changes in the profitability of investment. The method used is fairly standard in the corporate finance literature. ${ }^{11}$ For example, Kaplan (1989) uses an almost identical algorithm (except, as explained in the appendix, I use information about both the primary and secondary SIC industry codes assigned by Compustat). For each observation of $\Delta I / S$, I subtracted the median value of $\Delta I / S$ from a control group of Compustat segments which were in the same industry, but which were owned by companies which did not have an oil extraction segment. The algorithm for selecting the control group is detailed in the appendix; there were matches for 39 of the 40 observations.

Table $\mathrm{V}$ shows that, for both means and medians, both raw and industry-adjusted investment fell in 1986. The mean and median fall are significant at the five percent level, and again equal to about one percent of the investment to sales ratio. ${ }^{12}$ Following convention, the table reports two-sided p-values, although I am really trying to test a one-sided hypothesis; thus the p-values in the table are quite conservative.

\section{B. Robustness checks}

This section presents some basic robustness tests on the industry-adjusted results of Table V. First, I checked to see if the results were driven by any single observation. They weren't. ${ }^{13}$ Next, Table VI measures the dependent variables in a variety of different ways. In each case, the 
variables are industry-adjusted in the same manner as before. The first three columns normalize the change in investment by a constant 1985 denominator instead of looking at the change in the contemporaneous investment to sales ratio. Looking at the change in investment relative to 1985 sales and 1985 total assets does not change in the conclusions: there was a significant fall in 1986. The percentage change in investment, in the third column, appears quite skewed but the median is also significantly negative. The fourth column shows examines net segment investment (capital expenditures minus depreciation), as in Shin and Stulz (1995). Net investment to sales ratios fell significantly in $1986 .^{14}$

One potential objection to the evidence in the first four columns of Table VI is that the non-oil segment data may somehow be contaminated by the fact that the parent company also owns an oil exploration segment, despite the fact that I carefully screened the companies and read each segment's line-of-business description. For example, it could be that Burlington Northern's railroad division is more heavily involved in oil transportation compared to the control group of railroad divisions. There may be synergies between oil and non-oil segments (although it is difficult to imagine what they might be for, say, Mobil's Montgomery Ward retail division). Perhaps tax changes in this period affected oil companies more than other companies. Lastly, it could be that companies that own oil extraction segments also are regionally concentrated in oil-producing states. ${ }^{15}$

Although I cannot control for all of these factors, I can at least use a different control group that addresses some of these concerns. To provide a better control group, I used a group of 17 firms which owned an oil segment in 1985 but which were not oil-dependent (by my reckoning using ex ante data; less than 25 percent of their cash flow came from oil). These 17 
firms owned 36 non-oil segments. There is substantial overlap in the industries owned by the oil-dependent firms and this control group, with both groups including chemicals, mining, railroads, and agriculture If there is some hidden dependence on oil in these industries, then one might expect it to be reflected in the segments owned by not-oil-dependent oil firms. Of course, this control group is only useful to the extent that the hidden dependence depends on the existence of an oil segment rather than its quantitative size. If there is some hidden synergy is a function of the size of the oil segment, I have no hope of controlling for it.

The last column in Table VI shows evidence using both means and medians for industryadjusted data. Both the mean and the median change in investment were significantly lower for the oil-dependent oil firms compared to the control group of diversified, oil-owning firms. ${ }^{16}$

\section{Why did non-oil investment fall?}

The previous section documented that oil-dependent firms decreased their non-oil investment in 1986 . Why do we observe this relation between liquidity/collateral and investment? First, I attempt to disentangle the fall in collateral from the fall in cash flow. Second, and more broadly, I examine whether the fall in non-oil investment was likely to have helped or hurt the shareholders of oil companies. Last, I examine cash-flow investment correlations at the segment level.

\section{A. Cash Flow vs. Collateral}

Was the proximate cause of the decline in investment the decline in collateral, the decline in cashflow, or both? Since for this sample of oil-dependent companies the two are highly correlated, this is a difficult question. I address the question by collecting data on bond rating changes for the parent companies. Of the 39 segments for which industry-adjusted data is 
available, 17 had their parents' bond-rating downgraded by Moody's between May 1985 and May 1986. ${ }^{17}$ For these segments, the cost of external finance presumably rose.

Column 1 of Table VII uses regression evidence to show that these 17 segments had a fall in investment that was larger than the segments which did not have their debt downgraded. This difference, while quantitatively large at about one percent, is statistically insignificant. Is this relationship driven by the fact that downgrades are correlated with the 1986 fall in oil cash flow? To control for the ex post change in oil cash flow, I split the sample in half based on the size of the decline in oil cash flow. The variable EXPOSTSHOCK is equal to one for the 20 segments whose parents firms had the largest decline in oil cash flow relative to 1985 firm sales.

As can be seen in Table VII, both the downgrade and ex post shock variable do a miserable job of explaining the cross-section of investment changes, whether entered separately, together, or with other segment-level control variables (industry-adjusted changes in segment cash flow and sales). Both coefficients have the right sign and look plausibly large, however. I conclude from Table VII that it is impossible in this sample to untangle the effects of cash flow and collateral value changes.

\section{B. Underinvestment vs. Overinvestment}

The literature on imperfect information suggests underinvestment (relative to what would take place in perfect capital markets) may result from costly external finance, so that the fall in oil cash flow may have resulted in (increased) underinvestment in non-oil activities. On the other hand, principal-agent models (such as Jensen (1986)) stress that managers may overinvest free cash flow, so that the fall in oil cash flows may have prevented wasteful expenditure. Indeed, the oil industry was often cited as a possible case of overinvestment and an example of the salutary 
effects of hostile takeovers on corporate discipline. Blanchard, Lopez-de-Silanes, and Shleifer (1994) also conclude that agency problems may explain firms' use of cash flow. Both the underinvestment/information and overinvestment/agency approaches imply that when internal finance falls, investment falls.

In the context of diversified firms, previous research points in the direction of overinvestment. Lang and Stulz (1994) document that diversified firms have lower market values compared to less diversified firms. Berger and Ofek (1995) explain this negative effect of diversification using Compustat segment data similar to that used in this paper. They find that diversified firms tend to invest more than undiversified firms, tend to invest more in low $q$ industries, and tend to have below-average profits and cash flow. In sum, Berger and Ofek's evidence indicates that diversified firms tend to overinvest in and to subsidize money-losing segments.

Table VIII investigates these issues by examining industry-adjusted levels of non-oil investment to sales ratios, in 1985 and in 1986 . In 1985 , non-oil investment by oil firms was insignificantly different from industry levels; in 1986, non-oil investment was more than one percent below industry levels. Consequently, investment to sales ratios fell significantly. ${ }^{18}$ The level of investment in 1986 was below industry norms at marginal significance. ${ }^{19}$ Based on this table alone, one might conclude that oil companies were investing optimally in their non-oil businesses in 1985 , but were forced to underinvest in 1986 . The next table, however, tells a different story.

Table IX shows industry-adjusted levels of profitability and cash flow. Berger and Ofek (1995) found that segments owned by diversified firms had profit to sales ratios about two percent 
below similar segments owned by undiversified firms. ${ }^{20}$ As one might expect from Berger and Ofek's findings, non-oil segments owned by oil companies under-performed their industry peers in 1985 , with profit to sales ratios about two percent lower than industry median (this difference is marginally significant). In 1986, these non-oil segments performed about as well as the industry standard; thus industry-adjusted profitability rose significantly. One possible explanation for the improvement in performance in 1986 is that the oil cash shortfall gave managers newfound incentives to squeeze out more non-oil profits, just as LBO's and MBO's cause profits and cash flow to increase (Kaplan (1989)).

Although there could be several explanations for Tables VIII and IX, the industry-adjusted levels of investment and profitability seem quite consistent with the free cash flow hypothesis. In 1985 oil companies were pumping average amounts of capital expenditures into below-average segments. In 1986, oil companies cut back on this (possibly) wasteful expenditure, because they no longer had cash to (possibly) waste. Although Tables VIII and IX cannot prove that the non-oil segments were negative-NPV projects in 1985, they are certainly consistent with this idea and with the findings of Lang and Stulz (1994) and Berger and Ofek (1995).

\section{Subsidization and Self-financing}

To further explore the issue of subsidization of non-oil segments by oil segments, I examine the intersegment flow of cash in 1985 . Five out of the thirty-nine segments had capital expenditures in 1985 which exceeded their (pre-tax) cash flow; in some sense, their investment was subsidized using oil cash flow. ${ }^{21}$ Table $\mathrm{X}$ shows that these segments were dramatically different from the rest of the sample; they cut their industry-adjusted investment to sales ratios by a whopping eight percentage points more in 1986. This difference in means is highly significant, 
even controlling for changes in industry-adjusted segment cash flow and sales. Evidently, companies who were subsidizing their non-oil segments in 1985 slashed their investment in $1986 .{ }^{22}$

Last, I examine the relationship between segment investment and the both segment cash flow and oil cash flow, in regressions similar to equation (1). I examine 1985 and 1986 separately, to see how the change in the fortunes of the oil industry affected the allocation of capital across segments.

Table XI shows the results, regressing industry-adjusted levels of investment against own cash flow and oil cash flow. The variables are normalized by firm sales. In 1985, oil cash flow has a strong and statistically robust effect: for every dollar in oil cash flow, non-oil investment rises 12 or 13 cents. The coefficient on the segment's own cash flow appears imprecisely estimated; it is 0.35 in one specification but zero in another.

In 1986, in contrast, non-oil investment appears to be de-coupled from oil cash flow: the coefficient on oil-cash flow is zero. The segment's own cash flow now has a coefficient that is higher, highly significant, and robust across specifications. In summary: oil cash flow mattered for non-oil investment in 1985, but only own cash flow mattered in 1986.

Table XI is consistent with the following story. In 1985, oil companies were awash in cash, and subsidized poorly-performing non-oil businesses. In 1986, the parent companies stopped subsidizing their non-oil segments; these segments therefore only on their own cash flow to finance investment.

These results are comparable to existing estimates of equation (1). Using firm (not segment) data, Fazzari, Hubbard, and Petersen (1988) estimate a coefficient of 0.23 on cash flow for a similar group of companies 1970-1984. ${ }^{23}$ However, there are important differences between 
this regression and standard firm-level versions of equation (1). One difference is that, for consistency, I have industry-adjusted both the non-oil investment and the non-oil cash flow. Thus the estimates on the segment's own cash flow are intended to capture only the idiosyncratic component of the segment's cash flow.

One should be of course be cautious in interpreting multivariate regressions with only 39 observations, and all the different tables are based on the same 39 observations. Again, Tables $\mathrm{X}$ and XI cannot prove that the 1985 level of non-oil investment was excessive. Nevertheless, all the data appear consistent with previous research on the nature of value-reducing diversification during this period.

\section{Caveats}

The most significant departure from the existing literature is that the cash flow I observe is pre-tax operating income, since after-tax net income is not generally available. Thus OILCF and $C F$ do not represent true internal finance available to the firm. This problem may well be particularly acute for oil companies, for two reasons. First, US tax laws (which were changing or anticipated to change during this period) are a substantial factor in investment in capital-intensive industries like petroleum. Second, much of the income tax payment made by the large international oil companies in the sample was paid to foreign governments (e.g. Saudi Arabia). These payments to host countries were sometimes structured so as to ensure fixed profit margins for oil companies regardless of price. Thus, looking at pre-tax income would overstate the effect of the 1986 oil price crash for some companies. ${ }^{24}$ Using after-tax income would decrease the magnitude of the cash flow variable, and thus increase the magnitude of the coefficients.

Another potential way that taxation might affect our ability to make inferences from the 
results is by affecting the cost of capital. Companies with lower profits (or losses) may loose certain tax benefits and thus face a higher after tax cost of capital. Thus the cash/investment correlation might reflect changes in the cost of finance due to the tax code, not financial market imperfections. This problem is also present in the existing literature using firm-level data. So while the use of segment data improves on the existing literature by avoiding the profitability signaling component of cash flow, it does not avoid the tax signaling component.

A problem more specific to the 1986 episode is that major tax legislation was passed during this period; this legislation contained several provisions with differing effects on the cost of capital (portions of the law were implemented in 1986, with the bulk of the effect in 1987). If tax reform raised the cost of capital for oil firms more than other firms, then it may be driving the results.

\section{Future Extensions}

In principle, the approach used here can be used for many other episodes with financial shocks to diversified firms, for example exchange rate fluctuations (and other region-specific shocks for geographically diverse firms), commodity price movements, and business cycles.

For the case of oil firms, additional evidence could be gathered by moving in at least two directions. The first is to obtain plant-level data, for example from the Census Bureau's plant-level database. This would be useful both because it would supply more observations and because it would supply more information about the product of the individual plant. The second direction is to obtain more firm-level data for different periods of time. With a longer time series, we could begin to answer questions like: do negative shocks and positive shocks have the same effect on investment?

One desirable extension would be a more formal analysis of the profitability of investment. 
If a longer time series were available, forecasts of future profitability could be constructed in the tradition of Hall and Jorgenson (1967), Abel and Blanchard (1986), and Gilchrist and Himmelberg (1992).

Another extension would be to separate the effects of cash flow and collateral, perhaps by finding firms which have cash flow and collateral values that not positively correlated.

\section{Conclusion}

I conclude, based on the responses of oil companies' non-oil segments, that large decreases in cash flow and collateral value decrease investment. I confirm the findings from the literature on cash flow and investment: cash matters. Unfortunately, the sample size is fairly small, so that the investigation is fairly limited in scope; I feel confident only in testing relatively simple hypotheses. While statistical confidence levels are not extraordinarily high, they are moderately robust.

I also conclude that corporate segments are interdependent, so that combining different firms into a corporate whole has real consequences. Issues in the theory of the firm emerge naturally from this empirical investigation.

The sample of firms used in the paper include some of the largest corporations in the world (the median annual sales of the firms in Table II is about eight billion dollars). If one does not believe that asymmetric information or access to capital markets is likely to be a problem for such firms, one must find other explanations for the correlation of oil cash flow with non-oil investment. ${ }^{25}$ One explanation, suggested by previous research, is that large diversified companies overinvest in and subsidize under-performing segments. The evidence presented here is consistent with this explanation. 
The segment data presented here is potentially important for two reasons. First, segment data can provide a useful tool for examining questions of traditional interest in corporate finance. For example, this paper has explored the correlation of internal funds and investment, while Lang, Ofek, and Stulz (1995) use segment data to find the effect of leverage on investment and growth. Second, segment data will also be useful in exploring empirically novel issues in the theory of the firm, since it allows us to peer into the inner workings of the corporation. 
Page 24

\section{References}

Abel, Andrew B. and Olivier J. Blanchard, "The Present Value of Profits and Cyclical Movements in Investment, " Econometrica, March 1986, Vol 52 No 2, pp. 249-273.

Alchian, Armen, "Corporate Management and Property Rights," in Henry Mainne (ed.), Economic Policy and the Regulation of Corporate Securities 1969, 337-360.

Berger, Philip G., and Eli Ofek, "Diversification's Effect on Firm Value," Journal of Financial Economics, Vol. 371995 pp. 39-66.

Blanchard, Olivier, Florencio Lopez-de-Silanes, and Andrei Shleifer, "What Do Firms Do With Cash Windfalls?," Journal of Financial Economics December 1994 Vol 36 No 3, p337-360.

Fazzari, Steven, R. Glenn Hubbard, and Bruce Petersen. "Financing Constraints and Corporate Investment", Brookings Papers on Economic Activity, 1988, 141-195.

Gertler, Mark, and R. Glenn Hubbard. "Financial Factors in Business Fluctuations," in Financial Market Volatility. 1988, 33-71.

Gertner, Robert, David Scharfstein, and Jeremy Stein, "Internal versus External Capital Markets", Quarterly Journal of Economics, November 1994, Vol. CIX No. 4, p1211-1230..

Gilchrist, Simon, and Charles Himmelberg, "Evidence on the Role of Cash Flow for Investment", mimeo. 1992

Grossman, Sanford, and Oliver Hart, "The Costs and Benefits of Ownership: A Theory of Vertical and Lateral Integration," Journal of Political Economy 1986, 691-719.

Hall, Robert E. "Commentary on Financial Factors in Business Fluctuations," in Financial Market Volatility. 1988, 73-78.

Hall, Robert E. and Dale W. Jorgenson, "Tax Policy and Investment Behavior, "American Economic Review, 1967, pp. 391-414.

Holmstrom, Bengt, and Jean Tirole, "Market Liquidity and Performance Monitoring," Journal of Political Economy, 1993.

Hoshi, Takeo, Anil Kashyap, and David Scharfstein, "Corporate Structure, Liquidity and Investment: Evidence from Japanese Industrial Groups," Quarterly Journal of Economics, 1991, 33-60.

Jensen, Michael, "Agency Costs of Free Cash Flow, Corporate Finance, and Takeovers," American Economic Review 1986, 323-329.

Kaplan, Steven, "The Effects of Management Buyouts on Operating Performance and Value," Journal of Financial Economics, 1989, 217-254.

Kaplan, Steven N., and Luigi Zingales, "Do Financing Constraints Explain Why Investment is Correlated with Cash Flow?” NBER Working Paper \#5267, 1995.

Kashyap, Anil K., Owen A. Lamont, and Jeremy C. Stein, "Credit Conditions and the Cyclical Behavior of Inventories," Quarterly Journal of Economics, August 1994, Vol CIX No 3, pp. 565-592.

Lamont, Owen, "Cash Flow and Investment: Evidence from Internal Capital Markets," November 1993 unpublished paper.

Lang, Larry, Eli Ofek, and René M. Stulz, "Leverage, Investment, and Firm Growth," 
Journal of Financial Economics 1996, Vol 40, pp. 3-30.

Lang, Larry H.P., and René M. Stulz, “Tobin's $q$, Corporate Diversification, and Firm Performance," Journal of Political Economy, December 1994 Vol. 102 pp. 1248-1280.

Poterba, James M. "Comment on Financing Constraints and Corporate Investment," Brookings Papers on Economic Activity, 196-206.

Shin, Hyun-Han and René M. Stulz, "An analysis of the divisional investment policies of diversified firms," 1995 working paper.

Stein, Jeremy C., "Internal Capital Markets and the Competition for Corporate Resources," NBER Working Paper \#5101, 1995.

Whited, Toni M., "Debt, Liquidity Constrains, and Corporate Investment: Evidence from Panel Data," Journal of Finance, Sept 92, pp. 1425-1470. 


\section{Endnotes}

1. In contrast, industries which are major consumers of petroleum and energy as inputs revised their projected investment upwards. The three most energy intensive manufacturing industries (chemicals, paper, and primary metals) all raised their projected 1986 capital spending between October and April, consistent with the fact that their investment returns rose as a result of the oil price decline.

\section{Oil \& Gas Journal, 5/19/86}

3. A complete list of excluded industries is presented in the data appendix.

4. i.e. those segments with primary SIC code less than 6000 . This is standard because these industries have complex accounting variables.

5. I made one exception in deleting companies with an SIC code which indicated refining. Compustat assigned Fina, Inc. 's Chemicals segment a secondary SIC code indicating petroleum refining. After reading Fina's 1986 annual report and related documents, I did not agree with this classification, so I included this segment in the sample.

6. Of the 55 primary and secondary SIC codes of non-oil segments listed in Table III, I was able to find data for 29 of the industries. For each of these 29 industries, I ran a simple time-series regression with either $I / K$ or $\pi / K$ as the dependent variable (where $\pi$ is profits). Each regression had on the right hand side the real price of oil, a time trend, and the lagged dependent variable. For $I / K$, the coefficient on oil was negative in 19 out of the 29 regressions (it was never significant when positive, but was significant twice when negative). For $\pi / K$, the coefficient on oil was negative in 22 out of the 29 regressions (it was never significant when positive, but was significant 5 times when negative).

7. More precisely, they group firms by dividend payout ratios; the oil companies used in our sample would largely fall into the high dividend payout ratio category.

8. The sample of companies tracked by the DOE change over time, so this time series is affected by changes in composition.

9. why this is so is explored in Holmstrom and Tirole (1993).

10. $I / S$ declined for 27 out of the 40 segments. As shown in Table $\mathrm{V}$, the probability of flipping 40 coins and getting 27 heads or 27 tails is 0.04 .

11. In a previous version of this paper, Lamont (1993), I found that using a different method of industry-adjustment did not change the results. 
12. Using a different definition of oil-dependent does not alter the qualitative conclusions. Looking only at the twenty-one segments whose companies have more than 50 percent (instead of 25) of 1985 cash flow coming from oil, the means and medians for 1985-6 in Table $\mathrm{V}$ are slightly higher while the test statistics are about the same size.

13. The lowest t-statistic for the mean in Table V column (2) that I could generate by throwing out a single observation was 1.77 .

14. In a previous version of this paper, Lamont (1993), I performed additional robustness tests, examining the effect of multiple observations from the same firm and different methods of normalizing investment. I found that in general the results were robust.

15. Of course, this possible regional effect could work both ways. It could be that non-oil industries that sold their products nationally but were located in oil-related regions benefited, as wages, rents, and other business costs fell in those regions.

16. In a previous version of this paper, Lamont (1993), I explored the differences between these two groups of segments in more detail. Using a more precise way to compare the two groups, I rejected the hypothesis that the two groups experienced the same change in investment in 1986.

17. I was unable to find ratings for parent companies for 6 of the 39 segments.

18. Note that the last column of Table VIII reports the change in the industry-adjusted levels, while Table $V$ reports the industry-adjusted change in the levels. This slightly different procedure produces highly similar results.

19. Results are similar using capital expenditures net of depreciation.

20. In contrast, here I am comparing segments owned by oil companies to the entire universe of segments not owned by oil companies (which includes both diversified and undiversified parent firms).

21. This calculation is done on raw data, without industry-adjusting.

22. The number of "subsidized" segments in this sample of 39 fell from five in 1985 to two in 1986.

23. This estimate is for companies that pay high dividends. Most of the companies in the sample would fall into this category.

24. For example, Mobil (which did report both before- and after-tax segment income) had a fall in pretax oil income as shown in Table II, but after-tax net oil income was essentially flat. Due to growth in chemicals and merchandising, Mobil's net income actually rose between 1985 and 1986, as can be seen from Table II. 
25. Kaplan and Zingales (1995) also find that financial constraint does not appear to be a plausible explanation of cash flow/investment correlations. 


\section{Data Appendix}

This appendix describes detailed information about the procedures used to select and check the baseline sample of 40 segments and the control group of 36 segments used in the last column of Table VI.

For calculating which firms were oil-dependent, I wanted to use segment data to determine how much of the firms' cash flow came from the oil and gas extraction industry (code 13). Unfortunately, companies sometimes lumped different industries together in the same segment. I used Compustat's system of assigning two SIC codes to each segment in order to get around this problem. If a segment's primary SIC code was in code 13, I counted all of that segment as code 13; if only the secondary SIC code was code 13 , I counted only half the segment, since that is the highest possible proportion of the segment that could be in code 13 . Some companies in the sample, for example Chevron, did not disaggregate their petroleum business into refining and extraction but instead reported it as a single unit, which was assigned primary SIC code 2911 (refining) and secondary SIC code 1311 (extraction) by Compustat. I treated these units as if they had a primary SIC code of 1311.

I also read the line of business description for each segment from the companies' $10 \mathrm{~K}$ and annual reports. I excluded the following segments because I judged the segment to be adversely affected by the oil price shock: Freeport McMoran - segments including uranium and sulphur; Mitchell Energy - real estate segment in Houston, Texas; Nicor - marine service segment serving oil industry; Petrolite - chemicals used in oil production; Rowan Companies - operates airline in Alaska and Gulf of Mexico; Tidewater - marine service segment serving oil industry.

I then deleted segments with incomplete data for the 1985-6 period, segments from firms 
which were in bankruptcy between 1985-6, segments whose segment name was "OTHER" (since I found these segments often contained only corporate overhead or discontinued operations data), segments which (according to Compustat footnotes) had significant merger and acquisition activity in 1985-6 (because these accounting events could distort the variables of interest), and segments which had anomalous accounting data in 1985 (I removed segments which reported zero depreciation and segments with 1985 capital expenditures greater than sales).

Last, because the resulting sample contained very small segments which seemed to have more volatile accounting data, I excluded all segments with 1985 sales of less than $\$ 50$ million, or identifiable assets or depreciation of less than $\$ 5$ million in 1985

I also checked Compustat figures for accuracy. I found (apparently) typographical errors in the segment data for four companies: Amoco, ARCO, Occidental, and Schlumberger. Compustat's general policy was to report pre-tax operating income before special charges; however, for six companies (Burlington Northern, Canadian Pacific, Fluor, Goodyear, Union Pacific, and USX Corp) I found that Compustat had included special charges even though the company documents clearly stated and quantified the impact of the accounting charges. I therefore corrected the data so that cash flow was reported consistently for all companies.

For two companies I had to exclude subsidiaries companies; that is, to accept only one set of segment data from each corporate entity. These were: Occidental Petroleum (I excluded segment data from Canadian Occidental); and Royal Dutch/Shell (I included Compustat's computed "Royal Dutch/Shell Group" and excluded Royal Dutch, Shell Transport and Trade, and Shell Canada.)

All variables in Compustat are stated in US dollars, so that when the original data is in 
Canadian dollars or pounds sterling, Compustat converts using end-of-year exchange rates. Exchange rates changes did not appear to have a large affect on $\Delta I$.

I note that the inclusion of Placer Dome is slightly misleading, since Placer and Dome merged in 1987, so that the restated data reflects a corporate entity that did not exist in 1985-6. However, the 1985-6 $\Delta I, I$, the oil share, and other variables from the original company, Placer, are virtually identical to the variables of the successor company. Therefore, in order to get a continuous set of variables from 1985-7, I retained Placer Dome data as it existed in the Compustat database.

Industry-adjusting method: First, I screened on the size, data availability, and other criteria described previously. Then I tried to find segments with matching four digit primary and secondary SIC codes. If I could find at least five such segments, I used them as the control group; otherwise, I loosened the required match on the secondary SIC code to the three digit level and then to the two digit level. If this did not supply at least five segments, I reduced the level of precision to a three digit match on both the primary and secondary SIC code, and so on down to the two digit level. Using this procedure, I was able to calculate industry-adjusted figures for 39 of the 40 observation (I found no match for Dekalb Energy's agricultural seed division).

In calculating the share of oil in total firm sales, I divided the total oil sales by the sum of the sales of all firm segments. This does not necessarily equal total firm-level sales reported by the company due to miscellaneous sales, discontinued operations, intersegment sales, or unclassified sales. 
Table I: Profit Rates and Operating Statitistics for Petroleum Companies, 1980-1990

\begin{tabular}{|c|c|c|c|c|c|c|c|c|c|c|c|}
\hline & 1980 & 1981 & 1982 & 1983 & 1984 & 1985 & 1986 & 1987 & 1988 & \begin{tabular}{|l|l|}
1989 \\
\end{tabular} & 1990 \\
\hline \multicolumn{12}{|c|}{ Profit Rates for Lines of Business for FRS Petroleum Companies } \\
\hline Consolidated & 15.3 & 12.4 & 7.7 & 7.4 & 6.9 & 5.5 & 3.0 & 3.6 & 7.2 & 6.4 & 6.8 \\
\hline Petroleum & 19.2 & 16.6 & 12.5 & 11.3 & 10.4 & 10.5 & 5.5 & 6.2 & 7.3 & 6.7 & 9.5 \\
\hline US Petroleum & 17.5 & 16.1 & 12.7 & 10.3 & 9.4 & 9.4 & 3.0 & 4.9 & 6.3 & 5.8 & 7.9 \\
\hline Oil and Gas Production & 20.9 & 20.2 & 14.0 & 11.3 & 10.8 & 9.5 & 0.8 & 4.1 & 2.8 & 2.9 & 8.5 \\
\hline Refining and Marketing & 9.8 & 4.4 & 6.0 & 4.8 & 0.3 & 6.5 & 4.5 & 2.9 & 14.7 & 11.5 & 5.2 \\
\hline Pipelines & 15.1 & 15.6 & 20.8 & 16.6 & 20.8 & 15.0 & 13.2 & 12.8 & 9.6 & 10.2 & 11.2 \\
\hline Foreign Production & 23.0 & 17.7 & 11.8 & 14.1 & 13.3 & 13.8 & 12.8 & 9.5 & 9.9 & 8.7 & 12.5 \\
\hline Oil and Gas Production & 25.1 & 25.5 & 17.4 & 19.6 & 18.8 & 20.0 & 11.6 & 12.4 & 9.2 & 8.9 & 13.1 \\
\hline Refining and Marketing & 26.4 & 9.0 & 4.7 & 7.7 & 4.5 & 3.3 & 16.3 & 4.7 & 11.6 & 8.0 & 11.2 \\
\hline International Marine & 2.4 & -1.1 & -6.3 & -13.2 & -14.0 & -19.0 & 5.3 & -3.6 & 6.8 & 12.4 & 11.7 \\
\hline Coal & 5.6 & 6.1 & 4.4 & 5.0 & 6.2 & 4.6 & 2.7 & 5.1 & 6.7 & 5.0 & 3.3 \\
\hline Nuclear and Other Energy & -0.7 & -6.8 & -5.2 & 0.5 & -1.8 & -8.4 & -0.8 & 0.5 & -2.5 & -2.3 & 1.9 \\
\hline Nonenergy & 5.9 & 3.5 & 0.6 & 2.9 & 4.8 & 4.2 & 5.1 & 12.2 & 20.3 & 17.3 & 7.8 \\
\hline \multicolumn{12}{|c|}{ Operating Statistics for FRS Firms and for US Petroleum Industry } \\
\hline \multicolumn{12}{|c|}{$\begin{array}{l}\text { Net Production, Crude Oil And Natural Gas Liquids } \\
\text { (Billion barrels) }\end{array}$} \\
\hline FRS Companies & 2.09 & 2.07 & 2.08 & 2.06 & 2.09 & 2.12 & 2.09 & 2.07 & 2.10 & 1.91 & 1.81 \\
\hline US Industry & 3.71 & 3.69 & 3.67 & 3.75 & 3.81 & 3.81 & 3.71 & 3.57 & 3.32 & 3.24 & 3.27 \\
\hline \multicolumn{12}{|l|}{$\begin{array}{l}\text { Refinery Output } \\
\text { (Million barrels/day) }\end{array}$} \\
\hline FRS Companies & 12.22 & 11.28 & 10.63 & 10.38 & 11.00 & 10.92 & 11.46 & 11.71 & 12.03 & 11.41 & 11.31 \\
\hline US Industry & 15.35 & 14.66 & 14.01 & 13.69 & 14.27 & 14.19 & 14.93 & 15.09 & 15.43 & 15.65 & 15.91 \\
\hline \multicolumn{12}{|l|}{ Net Wells Completed } \\
\hline Exploratory & 926 & 1,159 & 625 & 513 & 597 & 539 & 258 & 356 & 224 & 363 & 347 \\
\hline Development & 1,917 & 2,081 & 1,580 & 1,586 & 1,982 & 1,776 & 647 & 911 & 822 & 922 & 1,164 \\
\hline
\end{tabular}

Notes: FRS Companies are a set of major petroleum companies which are tracked by the Department of Energy's Financial Reporting System. 
Table II: Firm Data: 1985-1986

\begin{tabular}{|c|c|c|c|c|c|c|}
\hline & \multirow[b]{2}{*}{ Company } & \multicolumn{2}{|l|}{ Ex ante } & \multicolumn{2}{|c|}{ Ex post } & \multirow{2}{*}{\begin{tabular}{|c|} 
Firm Size \\
1985 \\
Sales \\
(mil \$)
\end{tabular}} \\
\hline & & \begin{tabular}{|r|}
1985 \\
Percent of \\
Cash Flow \\
\end{tabular} & $\begin{array}{r}1985 \\
\text { Percent of } \\
\text { Sales }\end{array}$ & $\begin{array}{c}\Delta \mathrm{Net} \\
\text { Income }\end{array}$ & $\begin{array}{l}\Delta \text { Oil } \\
\text { Cash } \\
\text { Flow }\end{array}$ & \\
\hline & & & & \multicolumn{2}{|c|}{$\begin{array}{r}\text { Normalized By } \\
\text { Firm Sales }\end{array}$} & \\
\hline 1 & AMOCO CORP & 81 & 15 & -4 & -7 & 26,922 \\
\hline 2 & ATLANTIC RICHFIELD CO & 74 & 47 & 4 & -1 & 21,723 \\
\hline 3 & BURLINGTON NORTHERN & 28 & 28 & -17 & -2 & 8,651 \\
\hline 4 & CANADIAN PACIFIC & 28 & 7 & -2 & -1 & 10,754 \\
\hline 5 & CHEVRON CORP & 101 & 94 & -2 & -3 & 41,742 \\
\hline 6 & DEKALB ENERGY CO & 77 & 28 & -12 & -17 & 570 \\
\hline 7 & DU PONT & 49 & 12 & 1 & -4 & 29,314 \\
\hline 8 & FINA INC & 71 & 8 & -1 & -5 & 2,403 \\
\hline 9 & GRACE (W.R.) \& CO & 28 & 10 & -12 & -8 & 5,193 \\
\hline 10 & HOMESTAKE MINING & 32 & 19 & -0 & -6 & 298 \\
\hline 11 & IMPERIAL OIL LTD & 49 & 9 & -4 & -8 & 6,197 \\
\hline 12 & KERR-MCGEE CORP & 57 & 16 & -13 & -9 & 3,345 \\
\hline 13 & LITTON INDUSTRIES INC & 34 & 29 & -5 & -4 & 4,585 \\
\hline 14 & MOBIL CORP & 94 & 83 & 1 & -3 & 55,960 \\
\hline 15 & NOVA CORP OF ALBERTA & 41 & 29 & 6 & $\mathrm{NA}$ & 2,393 \\
\hline 16 & OCCIDENTAL PETROLEUM & 88 & 31 & -4 & -9 & 14,534 \\
\hline 17 & PHILLIPS PETROLEUM CO & 80 & 21 & -1 & -11 & 15,636 \\
\hline 18 & PLACER DOME INC & 43 & 27 & 9 & -7 & 302 \\
\hline 19 & ROYAL DUTCH/SHELL GRP & 82 & 19 & -0 & -4 & 81,562 \\
\hline 20 & SCHLUMBERGER LTD & 94 & 65 & -39 & -17 & 6,119 \\
\hline 21 & SOUTHDOWN INC & 49 & 19 & -12 & -5 & 325 \\
\hline 22 & TENNECO INC & 57 & 10 & -1 & -4 & 15,270 \\
\hline 23 & UNION PACIFIC CORP & 41 & 48 & -12 & -2 & 7,798 \\
\hline 24 & UNOCAL CORP & 70 & 10 & -1 & -2 & 10,738 \\
\hline 25 & USX CORP-CONSOLIDATED & 78 & 52 & \begin{tabular}{l|l}
-12 \\
\end{tabular} & -4 & 18,429 \\
\hline 26 & ZAPATA CORP & 103 & 68 & -62 & -12 & 289 \\
\hline
\end{tabular}

$E x$ ante cash flow and sales share are the percent of cash flow and firm sales that are derived from the petroleum extraction industry. Calculations described in the data appendix. Ex post change in net income and cash flow are the 1986-1987 dollar changes in firm net income and cash flow, divided by 1985 firm sales. 
Table III: Segment Data for Oil-dependent Firms

\begin{tabular}{|c|c|c|c|c|c|c|c|}
\hline & Company & Segment & $\Delta \mathrm{I} / \mathrm{S}$ & $\Delta \mathrm{CF} / \mathrm{S}$ & $\begin{array}{c}1985 \\
\text { Size } \\
\text { (Mil \$) }\end{array}$ & \multicolumn{2}{|c|}{$\begin{array}{l}\text { SIC } \\
\text { CODES }\end{array}$} \\
\hline $1 A$ & AMOCO CORP & CHEMICALS & 3.46 & 5.88 & 2905 & 2860 & 2820 \\
\hline $2 A$ & ATLANTIC RICHFIELD & SPEC \& INT. CHEMICALS & 2.38 & 1.97 & 2155 & 2869 & 2865 \\
\hline $3 / \mathrm{E}$ & BURLINGTON NORTHERN & FOREST PRODUCTS & -1.60 & 1.55 & 258 & 2411 & 2421 \\
\hline $4 \mathrm{E}$ & BURLINGTON NORTHERN & RAILROAD & -6.63 & -4.27 & 4098 & 4011 & 6519 \\
\hline 50 & CANADIAN PACIFIC LTD & FOREST PRODUCTS & 1.66 & 1.61 & 1546 & 2621 & 2421 \\
\hline 6. & CANADIAN PACIPIC LTD & RAILROAD & -3.40 & -1.38 & 2408 & 4011 & \\
\hline $7 C$ & CHEVRON CORP & CHEMICALS & -1.30 & 6.05 & 2246 & 2869 & 2865 \\
\hline $8 \mathrm{I}$ & DEKALB ENERGY CO & AGRICULTURAL SEED & -2.85 & -13.16 & 201 & 115 & 119 \\
\hline 91 & DU PONT & AG-IND. CHEMICALS & -0.67 & 10.72 & 3388 & 2879 & 2819 \\
\hline 101 & DU PONT & BIOMEDICAL PRODUCTS & 0.19 & 3.08 & 1016 & 3844 & 3841 \\
\hline 11 I & DU PONT & FIBERS & 1.43 & 10.77 & 4483 & 2824 & 2297 \\
\hline 12 I & DU PONT & INDUS.-CONS. PRODUCTS & 0.02 & -0.65 & 2780 & 3861 & 3679 \\
\hline 13 I & DU PONT & POLYMER PRODUCTS & -0.69 & 3.53 & 3379 & 2821 & 3081 \\
\hline 14 I & FINA INC & CHEMICALS & -0.95 & 9.36 & 405 & 2821 & 2821 \\
\hline 15 & GRACE (W.R.) \& CO & SPECIALTY BUSINESS & -0.91 & 0.42 & 787 & 2066 & 5192 \\
\hline 16 & GRACE (W.R.) \& CO & SPECIALTY CHEMICALS & -1.21 & -1.01 & 2254 & 2800 & 3086 \\
\hline 17. 1 & HOMESTAKE MINING & GOLD & -16.64 & 12.11 & 169 & 1041 & \\
\hline 181 & IMPERIAL OIL LTD & CHEMICALS & 0.81 & 4.08 & 542 & 2860 & 2870 \\
\hline 19 & KERR-MCGEE CORP & CHEMICALS & -2.33 & 5.22 & 483 & 2812 & 2816 \\
\hline 201 & LITTON INDUSTRIES & ADV. ELECTRONIC & 2.84 & -5.65 & 1863 & 3812 & 3679 \\
\hline 211 & LITTON INDUSTRIES & MARINE ENGIN. \& PRODTN & -0.32 & 0.05 & 975 & 3731 & 3663 \\
\hline 221 & MOBIL CORP & CHEMICAL & -0.40 & 4.86 & 2266 & 3081 & 2821 \\
\hline 231 & MOBIL CORP & RETAIL MERCHANDISING & -0.88 & 2.57 & 6073 & 5311 & 5961 \\
\hline $24[1$ & NOVA CORP OF ALBERTA & PETROCHEMICALS & 6.92 & 2.09 & 541 & 2869 & 2821 \\
\hline 25 & OCCIDENTAL PETROLEUM & AGRIBUSINESS & 0.40 & 0.37 & 6510 & 2011 & 6512 \\
\hline 26 & OCCIDENTAL PETROLEUM & CHEMICALS & -1.19 & 2.87 & 1621 & 2812 & 2874 \\
\hline 27 & PHILLIPS PETROLEUM & CHEMICALS & 0.72 & 8.65 & 2266 & 2869 & 2821 \\
\hline 28 & PLACER DOME INC & MINING & -0.43 & 1.10 & 221 & 1041 & 1021 \\
\hline 29 & ROYAL DUTCH/SHELL GRP & CHEMICALS & -1.09 & 8.52 & 8583 & 2800 & 2820 \\
\hline 30 & SCHLUMBERGER LTD & MEASUREMENT \& SYSTEMS & 0.51 & 0.13 & 1619 & 3820 & 7373 \\
\hline 31 & SOUTHDOWN INC & CEMENT AND CONCRETE & -4.54 & -0.29 & 265 & 3241 & 6519 \\
\hline 32 & TENNECO INC & AUTOMOTIVE PARTS & 0.77 & 1.65 & 1074 & 3714 & 5531 \\
\hline 33 & TENNECO INC & CHEMICAL & -1.87 & 2.34 & 841 & 2819 & 2800 \\
\hline 34 & TENNECO INC & PACKAGING & -0.72 & 0.25 & 851 & 2631 & 3089 \\
\hline 35 & TENNECO INC & SHIPBUILDING & -1.80 & -0.00 & 1801 & 3731 & 3610 \\
\hline 36 & UNION PACIFIC CORP & TRANSPORTATION & -4.39 & 6.87 & 3786 & 4011 & 4213 \\
\hline 37 & UNOCAL CORP & CHEMICALS & -2.39 & 0.44 & 1217 & 2873 & 2999 \\
\hline 38 & UNOCAL CORP & METALS & -9.41 & -3.42 & 129 & 1099 & 1061 \\
\hline 39 & USX CORP & STEEL & -1.44 & -8.72 & 6263 & 3312 & 1011 \\
\hline 40 & ZAPATA CORP & MARINE PROTEIN & -10.29 & 16.45 & 93 & 2048 & 2077 \\
\hline
\end{tabular}


Notes to Table III: $\Delta$ I/S is the change in the segment investment to sales ratio between 1985 and 1986. $\Delta \mathrm{CF} / \mathrm{S}$ is the change in the segment cash flow to sales ratio between 1985 and 1986. Cash flow equals pretax operating profit plus depreciation. Expressed as percentage points. 


\begin{tabular}{|l|l|l|l|}
\hline \multicolumn{4}{|c|}{ Table IV: Raw segment I/S, } \\
\hline \multicolumn{4}{|c|}{$1985-1987$} \\
\hline & 1985 & 1986 & 1987 \\
\hline No. of Obs. & 40 & 40 & 40 \\
\hline \multicolumn{4}{|c|}{} \\
\hline Mean & 7.94 & 6.48 & 6.24 \\
\hline \multicolumn{4}{|c|}{} \\
\hline Median & 6.91 & 6.13 & 5.84 \\
\hline
\end{tabular}

I is segment capital expenditure and $S$ is segment sales. I/S expressed as percentage points. 


\begin{tabular}{|c|c|c|}
\hline \multicolumn{3}{|c|}{$\begin{array}{c}\text { Table V: } \Delta \mathrm{I} / \mathrm{S}, \\
1985-1986\end{array}$} \\
\hline & Raw & $\begin{array}{l}\text { Industry- } \\
\text { Adjusted }\end{array}$ \\
\hline No. of Obs. & 40 & 39 \\
\hline Mean & -1.46 & -1.41 \\
\hline t-statistic & $(2.34)$ & $(2.06)$ \\
\hline p-value & $(0.02)$ & $(0.05)$ \\
\hline Median & -0.90 & -0.80 \\
\hline Z-statistic & $(2.51)$ & $(2.18)$ \\
\hline p-value & $(0.01)$ & $(0.03)$ \\
\hline $\begin{array}{l}\text { Number } \\
\text { positive }\end{array}$ & 13 & 12 \\
\hline p-value & $(0.04)$ & $(0.02)$ \\
\hline
\end{tabular}

Dependent variable: $\Delta I / S$, where I is segment capital expenditure and $S$ is segment sales. Expressed as percentage points. Median: The Z-statistic is the Wilcoxon signed-rank test, which tests the hypothesis that the observations are IID and symmetrically distributed around zero. Number positive: the 2-sided p-value is the probability of observing at most this number of positive or negative values, under the null hypothesis that the observations are independent and prob[positive] $=.5$. Industry-adjustment method described in the text. 


\begin{tabular}{|c|c|c|c|c|c|}
\hline \multicolumn{6}{|c|}{$\begin{array}{l}\text { Table VI: Alternative Measures of Industry-Adjusted } \Delta \mathrm{I} \\
\qquad 1985-1986\end{array}$} \\
\hline & \multicolumn{4}{|c|}{ Alternative Measures } & \multirow{2}{*}{$\begin{array}{l}\text { Alternative } \\
\text { Sample } \\
\Delta \mathrm{I} / \mathrm{S}\end{array}$} \\
\hline & ${ }_{5}^{(\Delta \mathrm{I}) / \mathrm{S}_{8}}$ & $(\Delta \mathrm{I}) / \mathrm{A}_{85}$ & $(\Delta \mathrm{I}) / \mathrm{I}_{85}$ & $\Delta(\mathrm{I}-\delta) / \mathrm{S}$ & \\
\hline No. of Obs. & 39 & 39 & 39 & 39 & 75 \\
\hline Mean & -1.54 & -1.09 & -6.34 & -1.74 & -2.56 \\
\hline t-statistic & $(2.31)$ & (2.26) & $(0.48)$ & (2.47) & (2.49) \\
\hline$p$-value & $(0.02)$ & $(0.02)$ & $(0.63)$ & $(0.02)$ & $(0.01)$ \\
\hline Median & -1.02 & -1.32 & -14.96 & -1.25 & -1.53 \\
\hline Z-statistic & $(2.20)$ & $(2.20)$ & $(2.20)$ & $(2.56)$ & $(2.57)$ \\
\hline $\mathrm{p}$-value & $(0.03)$ & $(0.03)$ & $(0.03)$ & $(0.01)$ & $(0.01)$ \\
\hline $\begin{array}{l}\text { Number } \\
\text { positive }\end{array}$ & 15 & 15 & 15 & 12 & NA \\
\hline$p$-value & $(0.20)$ & $(0.20)$ & $(0.20)$ & $(0.02)$ & NA \\
\hline
\end{tabular}

All variables industry-adjusted and expressed as percentage points. Alternative measures: $(\Delta I) / S_{85}$ is the change in investment normalized by 1985 segment sales. $(\Delta \mathrm{I}) / \mathrm{A}_{85}$ is the change in investment normalized by 1985 segment total assets. $(\Delta I) / I_{85}$ is the percentage change in investment between 1985 and 1986 . $\Delta(\mathbf{I}-\delta) / \mathrm{S}$ is the change in the net investment ratio (capital expenditures minus depreciation divided by sales) between 1985 and 1986. Median: The Z-statistic is the Wilcoxon signed-rank test, which tests the hypothesis that the observations are IID and symmetrically distributed around zero. Number positive: the 2 -sided p-value is the probability of observing at most this number of positive or negative values, under the null hypothesis that the observations are independent and prob[positive] $=.5$. Alternative sample: Uses both the base sample of 39 segments and an additional group of 36 segments described in the text. Mean: the coefficient on the dummy variable for oil-dependent firms in a regression including only a dummy and a constant. Constant term not shown. Median: the difference between the medians of the oil-dependent and not-oil-dependent sample. The Z-statistic is the Wilcoxon-rank sum test, which tests the hypothesis that the two samples have the same IID distribution. The reported 2-sided p-values are two sided. 


\begin{tabular}{|c|c|c|c|c|}
\hline \multicolumn{5}{|c|}{$\begin{array}{c}\text { Table VII : Ex post regression evidence on } \Delta \mathrm{I} / \mathrm{S} \text { : } \\
\text { Cash flow vs. Bond ratings }\end{array}$} \\
\hline CONSTANT & $\begin{array}{l}-0.99 \\
(1.07)\end{array}$ & $\begin{array}{l}-1.06 \\
(1.06)\end{array}$ & $\begin{array}{l}-0.46 \\
(0.37)\end{array}$ & $\begin{array}{l}-0.48 \\
(0.37)\end{array}$ \\
\hline DOWNGRADE & $\begin{array}{l}-0.97 \\
(0.70)\end{array}$ & & $\begin{array}{l}-1.13 \\
(0.79)\end{array}$ & $\begin{array}{l}-1.56 \\
(0.99)\end{array}$ \\
\hline EXPOSTSHOCK & & $\begin{array}{l}-0.69 \\
(0.50)\end{array}$ & $\begin{array}{l}-0.89 \\
(0.63)\end{array}$ & $\begin{array}{l}-0.75 \\
(0.47)\end{array}$ \\
\hline$\Delta \mathrm{CF} / \mathrm{S}$ & & & & $\begin{array}{l}0.00 \\
(0.02)\end{array}$ \\
\hline$(\Delta S) / S$ & & & & $\begin{array}{l}-0.04 \\
(0.72)\end{array}$ \\
\hline Adj R2 & -0.01 & -0.02 & -0.03 & -0.07 \\
\hline
\end{tabular}

$\mathrm{N}=39$. T-statistics in parenthesis. The dependent variable is industry-adjusted $\Delta \mathrm{I} / \mathrm{S}$, the change in the ratio of capital expenditures to sales for non-oil segments between 1985 and 1986 . DOWNGRADE is a dummy variable equal to 1 for the 17 segments whose parent firms had their debt downgraded by Moody's between 1985-86. EXPOSTSHOCK is a dummy variable equal to one for the 20 segments whose parent firms experienced a decline in oil cash flow between 1985 and 1986 that was greater than $4.3 \%$ of their 1985 sales. $\Delta \mathrm{CF} / \mathrm{S}$ is the industry-adjusted change in the cash flow to sales ratio between 1985 and 1986. $(\Delta \mathrm{S}) / \mathrm{S}$ is the industry-adjusted percent change in segment sales between 1985 and 1986. 


\begin{tabular}{|c|c|c|c|c|}
\hline \multicolumn{5}{|c|}{ Table VIII: Investment } \\
\hline & & 1985 & 1986 & $\Delta \mathbf{1 9 8 5 - 8 6}$ \\
\hline \multicolumn{5}{|l|}{$\mathbf{I} / \mathbf{S}$} \\
\hline & Mean & 0.62 & -1.05 & -1.66 \\
\hline & t-statistic & $(0.75)$ & (1.95) & $(2.50)$ \\
\hline & p-value & $(0.46)$ & $(0.06)$ & $(0.02)$ \\
\hline & Median & -0.18 & -1.49 & -1.06 \\
\hline & Z-statistic & $(0.15)$ & $(1.91)$ & $(2.79)$ \\
\hline & p-value & $(0.88)$ & $(0.06)$ & $(0.01)$ \\
\hline & $\begin{array}{l}\text { Number } \\
\text { positive }\end{array}$ & 17 & 17 & 13 \\
\hline & p-value & $(0.52)$ & $(0.52)$ & $(0.05)$ \\
\hline
\end{tabular}

$\mathrm{N}=39 . \quad$ I/S is segment capital expenditure divided by segment sales, industry-adjusted and expressed as percentage points. The last column is the difference in the first two columns. Median: The Z-statistic is the Wilcoxon signed-rank test, which tests the hypothesis that the observations are IID and symmetrically distributed around zero. Number positive: the 2-sided $\mathrm{p}$-value is the probability of observing at most this number of positive or negative values, under the null hypothesis that the observations are independent and prob[positive] $=.5$. 


\begin{tabular}{|c|c|c|c|c|}
\hline \multicolumn{5}{|c|}{ Table IX: Profitability } \\
\hline & & 1985 & 1986 & $\Delta \mathbf{1 9 8 5 - 8 6}$ \\
\hline \multicolumn{5}{|l|}{$\pi / \mathbf{S}$} \\
\hline & Mean & -1.82 & 0.29 & 2.11 \\
\hline & t-statistic & $(1.79)$ & $(0.26)$ & $(2.43)$ \\
\hline & p-value & $(0.08)$ & $(0.80)$ & $(0.02)$ \\
\hline & Median & -2.58 & 0.82 & 2.34 \\
\hline & Z-statistic & $(1.69)$ & $(0.53)$ & $(2.75)$ \\
\hline & p-value & $(0.09)$ & $(0.60)$ & $(0.01)$ \\
\hline & Number positive & 16 & 22 & 28 \\
\hline & p-value & $(0.34)$ & $(0.52)$ & $(0.01)$ \\
\hline \multicolumn{5}{|l|}{ CF/S } \\
\hline & Mean & -2.05 & -0.96 & 1.09 \\
\hline & t-statistic & $(2.00)$ & $(0.88)$ & (1.38) \\
\hline & $\mathrm{p}$-value & $(0.05)$ & $(0.39)$ & $(0.17)$ \\
\hline & Median & -0.24 & -0.20 & 0.48 \\
\hline & Z-statistic & $(1.63)$ & $(0.61)$ & $(1.31)$ \\
\hline & p-value & $(0.10)$ & $(0.54)$ & $(0.19)$ \\
\hline & Number positive & 17 & 18 & 21 \\
\hline & p-value & $(0.52)$ & $(0.75)$ & $(0.75)$ \\
\hline
\end{tabular}

$N=39$. $\pi / S$ is segment operating income divided by segment sales. $C F / S(=(\pi+\delta) / S)$ is segment operating income plus segment depreciation divided by segment sales. Variables are industry-adjusted and expressed as percentage points. Median: The Z-statistic is the Wilcoxon signed-rank test, which tests the hypothesis that the observations are IID and symmetrically distributed around zero. Number positive: the 2-sided p-value is the probability of observing at most this number of positive or negative values, under the null hypothesis that the observations are independent and prob[positive] $=.5$. 


\begin{tabular}{|l|l|l|}
\hline \multicolumn{3}{|c|}{ Table X : Subsidies and $\Delta \mathrm{I} / \mathrm{S}$} \\
\hline & $\mathbf{( 1 )}$ & $(\mathbf{2})$ \\
\hline CONSTANT & $\begin{array}{l}-0.37 \\
(0.65)\end{array}$ & $\begin{array}{l}-0.46 \\
(0.76)\end{array}$ \\
\hline SUBSIDY & $\begin{array}{l}-8.10 \\
(5.07)\end{array}$ & $\begin{array}{l}-8.32 \\
(5.13)\end{array}$ \\
\hline$\Delta$ CF/S & & $\begin{array}{l}-0.01 \\
(0.12)\end{array}$ \\
\hline$(\Delta$ S $) / S$ & & -0.04 \\
& & $(1.16)$ \\
\hline & & \\
\hline Adj R2 & 0.39 & 0.38 \\
\hline
\end{tabular}

$\mathbf{N}=39$. T-statistics in parenthesis. The dependent variable is industry-adjusted change in investment to sales ratios for non-oil segments between 1985 and 1986. CF is segment cash flow $=\pi+\delta$. SUBSIDY is a dummy variable equal to one for the 5 segments which had $C F<I$ in 1985 , where neither I nor CF have been industry-adjusted. $\Delta \mathrm{CF} / \mathrm{S}$ is the industry-adjusted change in the cash flow to sales ratio between 1985 and 1986. $(\Delta \mathrm{S}) / \mathrm{S}$ is the industry-adjusted percent change in segment sales between 1985 and 1986. 


\begin{tabular}{|c|c|c|c|c|}
\hline \multicolumn{5}{|c|}{$\begin{array}{c}\text { Table XI: Levels of Investment } \\
\text { and Segment and Oil Cash Flow } \\
1985 \text { vs. } 1986\end{array}$} \\
\hline & \multicolumn{2}{|l|}{1985} & \multicolumn{2}{|l|}{1986} \\
\hline & (1) & (2) & (3) & (4) \\
\hline CONSTANT & $\begin{array}{l}-1.21 \\
(1.52)\end{array}$ & $\begin{array}{l}-2.61 \\
(3.24)\end{array}$ & $\begin{array}{l}-1.11 \\
(0.30)\end{array}$ & $\begin{array}{l}0.06 \\
(0.11)\end{array}$ \\
\hline $\mathrm{CF} / \mathrm{FS}$ & $\begin{array}{l}0.35 \\
(1.83)\end{array}$ & $\begin{array}{l}-0.04 \\
(0.19)\end{array}$ & \begin{tabular}{|l}
0.40 \\
$(3.55)$
\end{tabular} & \begin{tabular}{|l}
0.43 \\
$(3.26)$
\end{tabular} \\
\hline OILCF/FS & $\begin{array}{l}0.13 \\
(2.40)\end{array}$ & $\begin{array}{l}0.12 \\
(2.62)\end{array}$ & $\begin{array}{l}-0.00 \\
(0.09)\end{array}$ & $\begin{array}{l}-0.01 \\
(0.24)\end{array}$ \\
\hline S/FS & & $\begin{array}{l}0.07 \\
(3.46)\end{array}$ & & $\begin{array}{l}-0.00 \\
(0.42)\end{array}$ \\
\hline Adj $R 2$ & 0.17 & 0.35 & 0.23 & 0.21 \\
\hline
\end{tabular}

$\mathrm{N}=39$. T-statistics in parenthesis. FS is total firm sales. The dependent variable is $\mathrm{I} / \mathrm{FS}=\mathrm{I} / \mathrm{S} * \mathrm{~S} / \mathrm{FS}$ for non-oil segments, where I/S is industry-adjusted. S/FS measures the relative size of the segment by taking the ratio of segment sales to total firm sales. $\mathrm{CF} / \mathrm{FS}=$ $\mathrm{CF} / \mathrm{S} * \mathrm{~S} / \mathrm{FS}$ where $\mathrm{CF} / \mathrm{S}$ is the industry-adjusted non-oil cash flow to sales. OILCF/FS is the (unadjusted) oil cash flow to firm sales ratio. 


\section{Figure 1:Real Crude Oil Prices 1982 Dollars per Barrel}

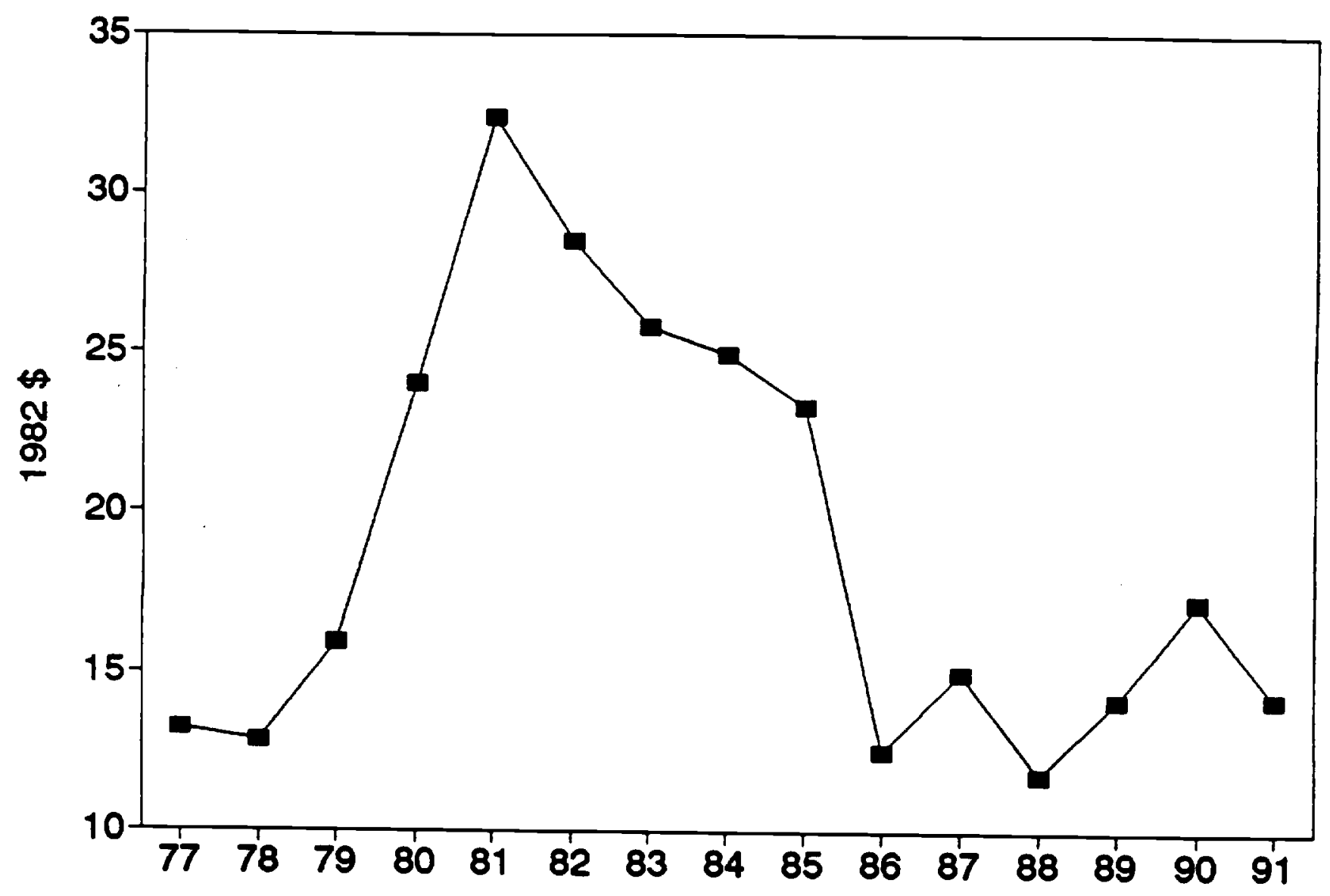


Figure 2: Nonenergy Asset Disposals As a percent of net capital stock

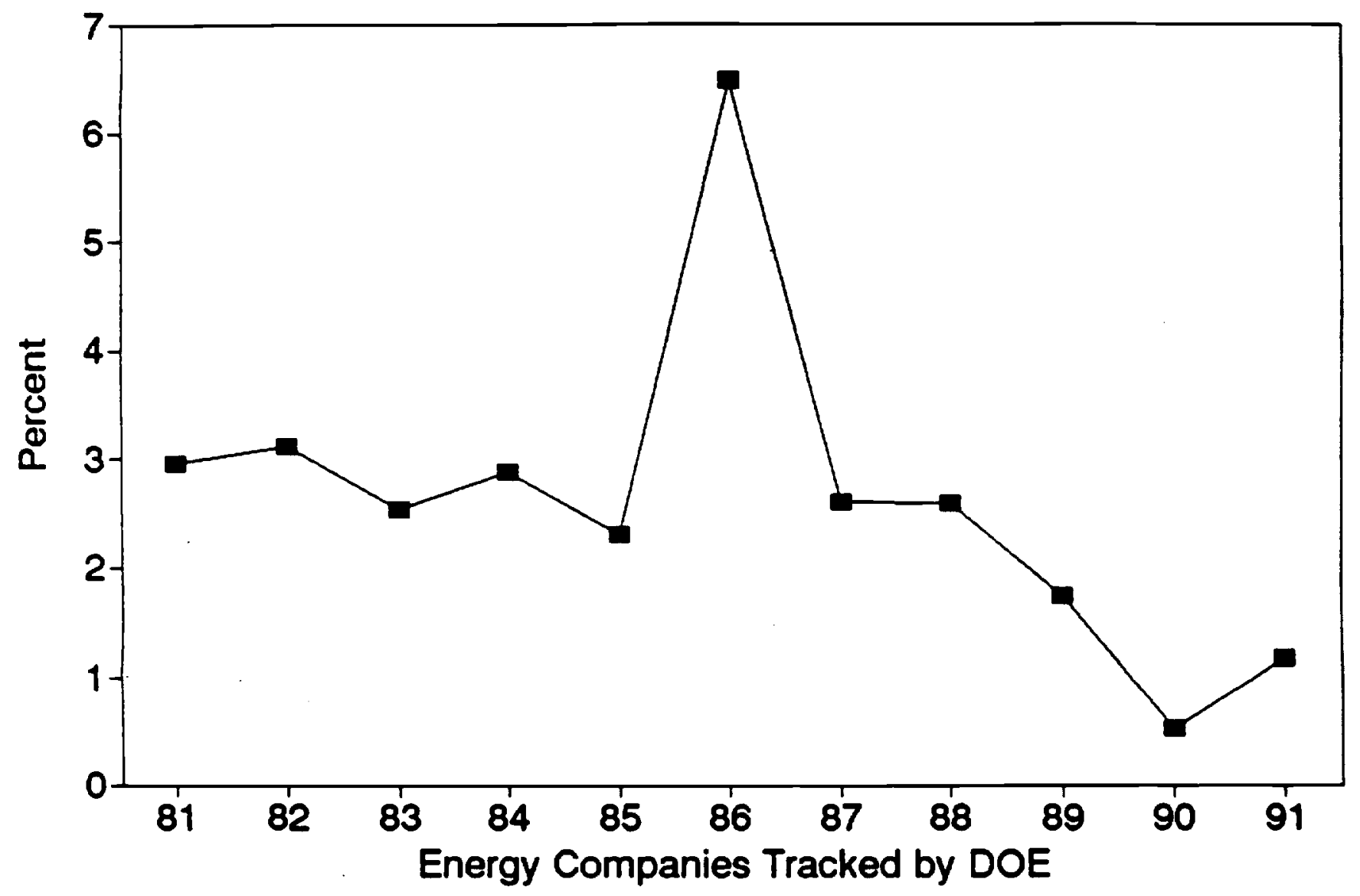

